\title{
COMPANY MERGER AND ACQUISITIONS FINANCIAL RESULT EVALUATION
}

\section{Kaspars Mucenieks}

Mg. oec.

\begin{abstract}
The success of company merger and acquisition process can be seen in many ways, as it is highly dependent on how its performance is defined. Some authors say that executives and experts in the companies are most appropriate in explaining the success of the merger and merger, while comparing the initial goals with the post merger results. Others prefer accounting methods, while relying on preand post-merger ratio analysis Finally, some authors prefer to measure merger and merger success by analysing statements and the resulting abnormal returns in stock markets. The aim of this article is to analyse what financial ratios affect mergers and acquisitions in Latvia. The scientific problem of the article is that impact of knowledge creation and company financial data after merger and acquisition deals has been not measured, lack of information about financial results. To reach the aims of the article scientific methods have been used such as literature review, comparable analyse, studies of statistics on merger un acquisition deal in Latvia. For data analysis there were used indicators of descriptive statistics, correlation analysis.
\end{abstract}

Keywords: Latvia, merger, acquisition, integration, financial ratio, EBITDA / Turnover, MA index

\section{Introduction}

The mergers and acquisitions (M\&A) process is relevant for companies looking to expand their business and strengthen their market position. $\mathrm{M} \& \mathrm{~A}$ are planned and implemented as a long-term strategy of the company rather than a short-term financial gain (Archibigi, 2002). When business leaders can no longer achieve their goals through internal growth, they often start mergers or takeovers (Recardo, Toterhi, 2015, Fiocco, 2016). Companies use the M\&A process to increase financial stability and remain competitive in global markets (Sobolev, 2015).

There are various definitions of mergers and acquisitions in the literature, and a breakdown of these processes. Many authors (Capron, Haleblian, Devers, McNamara, Carpenter, Davison) define the terms "merger" and "acquisition" in the context of strategic business. The difference between the two terms is manifested in integration and time. With the purchase, the buyer takes the lead in deciding the fate and structure of the business. 
Changes resulting from the purchase (depending on the circumstances) are usually implemented quickly and autocratically. A business combination is the combination of two or more independent market participants, to become a single market participant or to gain decisive influence over other market participants. Mergers can be considered when two separate companies decide to continue operating in one organization. Business combinations can take the following forms:

- equal merger, when two similar companies decide to continue working together as a new, single company; and

- unequal merger, when two or more companies are merged, offering the owners of one company securities (shares) in the combined company as a reward for relinquishing control of their company (Damodaran, 2001).

A business acquisition is a type of transaction in which one company takes over the complete management of another company through a purchase transaction, with the aim of making the other a subsidiary or incorporating it into its current business. In the course of an acquisition, the shares or assets of one company are transferred to another by way of sale. An effective takeover strategy ensures significant company growth (Ashon, Cook, Schmitz, 2003). The author shares the view of J. E. Ashon and $\mathrm{F}$. Cook that most companies use a takeover strategy to improve their business and reduce costs. Therefore, the author emphasises that a company that wants to succeed in its operations needs an easy-to-use method to help it manage the merger and acquisition process.

Taking over the content of its execution can be both "friendly" and "unfriendly":

- friendly takeover - management of the takeover object agrees to the takeover transaction and the company shares are transferred to the acquiring company; and/or

- unfriendly takeover - the company tries to buy another company, despite the fact that the (target) company (including the company management) does not agree to such a transaction (Damodaran, 2001).

\section{Company merger and acquisition strategy types}

The environment in which a company operates is dynamic, influenced by the strategies of the companies and their design. The strategy formulation and management process are an endlessly integrated process that requires continuous evaluation and necessary adjustments. The following can be used to merge and take over a business: horizontal integration, vertical integration, tied or unrelated diversification. 
The horizontal integration transaction brings together companies in the industry that are direct competitors in the product and market segment. Horizontal company integrations can lead to productivity gains, especially when companies are similar, but some of their different resources are complementary (Kapoor, Lim, 2007). Horizontal integration reduces company costs, industry competition, buyer and supplier strength.

In a vertical integration transaction, the customer and the manufacturer or the supplier and the manufacturer are united. This can happen through the merger of two or more companies, as well as new business start-ups. Vertical integration is the acquisition of a supplier or distributor of one or more goods and services of an undertaking (Gabrielsen, 2003). Vertical integration is used to grow and gain a larger market. Companies often use vertical and horizontal integration to gain additional market power (Haleblian, Devers, McNamara, Carpenter, Davison, 2009, Lui, 2016).

Vertical integration is divided into flow integration and backflow integration (Fiocco, 2016). The company that makes the decision to implement vertical integration is usually interested in increasing its competitiveness in its core business. One of the benefits of using this strategy is the ability to create entry barriers to overcome for newcomers to the industry. If the company integrates in the upstream direction, it acquires control over the most important raw materials, but in the case of downstream integration, the company acquires control over the distribution channels. This in turn reduces competition in the industry and allows the company to maintain higher sales prices and higher profits.

In Latvia, the horizontal mode of integration is used more and more by combining companies operating in the same sector and competing with similar products and similar market strategy. The main goal of the merger is to keep costs as low as possible, eliminating a number of duplicate functions and saving on redundancies. Significant savings are achieved by reducing marketing and advertising costs. Examples of horizontal mergers include Amber Beverage Group and Interbaltija AG (the largest Latvian companies in the Top 500 for 2016, 2017). Horizontal mergers by merging competitors may lead to monopoly or excessive business concentration. This possibility is reduced by the condition that merger transactions in Latvia require the permission of the Competition Council.

In the case of vertical integration, the company chooses to add companies that offer goods or services closer to inputs or consumers. This combination helps the company to better control the entire so-called value chain - from the raw material to the moment the product reaches the consumer. Such a merger model was chosen by SIA Latvijas mobilais telefons and SIA Zetcom (the largest Latvian companies in the Top 500 for 2007, 2008). From Zetcom SIA this deal was profitable - new services, 
wider technical solutions, possibility to offer lower tariffs to customers. A potentially similar service, as developed by Zetcom, could also have been created by Latvijas Mobilais Telefons, but in this case, preference was given to the acquisition of a ready-made company, thereby significantly reducing the time needed to develop a new line of business. distribution market. Vertical integration has also taken place in the production and marketing of alcoholic beverages, with manufacturers seeking to increase their influence in the distribution of beverages. The other trend is the regional consolidation of these distribution chains. There are several examples of such processes: In 2007, S.P.I. Group obtained permission from the Latvian Competition Council to merge AV\&D and Interlat, which had been acquired by S.P.I. Group subsidiary S.P.I. Worldwide Trade Limited (the largest Latvian companies in the Top 500 for 2007, 2008), the Estonian company Liviko in 2007 acquired the Latvian wholesaler L.I.O.N. \& Co (Latvia's largest companies in the Top 500 for 2007, 2008). Vertical bundling in the form of a merger of suppliers and customers can close the market to potential competitors.

Expanding bundling occurs when firms that offer the same product, but in different markets (for example, geographically), and product bundling when firms that offer different, but related products in the same market.

There is also the possibility of merging with a company operating in another industry and not related to the current business - diversification. Such deals do not give companies the opportunity to win new clients or control a larger market share - they can be done to reduce the volatility of riskier line of business with a more stable line of business (real estate leasing).

Changes in the business environment make it necessary to look for new ways and means to enhance the competitiveness of businesses and to gain the advantages of being more competitive. Several authors, for example, K. H. Heimerik, M. Schijven, S. Gates (Heimerik, Schijven, Gates, 2012), M. Hits (Hitt, 2001), A. M. McGahan (2004) believes that competitiveness benefits from a number of factors:

- making the best use of the resources available to the company;

- ability to react promptly to changes in market demand;

- ability to react promptly to changes in technology; and

- Adequate set of capabilities and resources of the company that set it apart from its competitors.

According to $\mathrm{M}$. Porters, the competitive advantage of a company is mainly due to the position stability of a company that offers interchangeable goods and services (Mavḷutova, 2010). Prahalada and Hamel emphasised the importance of the company's different skills in creating a competitive advantage and the role of management in the process. $\mathrm{K}$. Prahalad and G. Hamel put forward three main theses. First, a competitive advan- 
tage depends on the ability of a company to develop the key competences that will underpin the development of innovative products at a faster and lower cost than its competitors. Second, it is necessary to establish a link between one or more company skills and the end product. Third, business management must pay close attention to strategy development and implementation. The aim of the strategy is to determine what key competences a company should develop (Volvenkins, 2012). Optimal use and development of the company's internal resources contributes to the development of core competencies, providing competitive advantages and, together with them, long-term profitability of the company (Mavlutova, 2010). Barney (2006) looks at two perspectives on analysis - internal and external. An internal perspective analyses the resources (both tangible and intangible) and skills available to a company to develop its core competencies to provide a competitive advantage over competing market players. The external perspective can be divided into three types of strategic analysis: general analysis, industry (market) analysis and competitor analysis. In contrast, Caune said that "a competitive advantage is the value-creating activities and resources of a company that provide asset returns above the industry average and can sustain them for many years" (Volvenkins, 2012).

Some companies use takeovers to increase their growth rate compared to their competitors. If such a company successfully executes the transaction, it gives the company an advantage over its competitors in terms of market power and position (McNamara, Haleblian, Dykes, 2008). Takeovers provide much faster growth and thus easier entry into new markets. Sometimes organic growth can provide greater long-term value (Lee, Lieberman, 2010).

Acquiring the knowledge of the acquiring company and developing its capacity are additional reasons for the willingness to take over other organisations. These companies often have employees with unique skills, organisational technology or knowledge that the other company can only gain as a result of the first takeover. Acquisition of knowledge by takeovers is often reflected in cross-border takeovers (Lin, Peng, Yang, Sun, 2009). Although acquiring companies may acquire knowledge in various fields, they are usually related to the relevant market (for example, customers, distributors, suppliers and national binding legislation) (Chen, 2008).

In a competitive environment, some takeovers are used to diversify their business, thus reducing their dependence on a highly competitive market. Companies carry out takeovers to gain tax relief or to reduce the risk associated with doing business (Miller, Le Breton-Miller, Lester, 2010).

The author emphasises that companies use takeovers for various reasons. The takeover allows the acquiring company to reduce competition 
in the industry by reducing duplication through integration. The merger is important for companies looking to expand their business and strengthen their market position. Unlike in the case of a takeover, one company buys another, there is no exchange of shares or merger into a new company. A vertical merger transaction (i.e., supplier-customer merger) can resolve a number of coordination and pricing policy issues. Conversely, the benefits of a horizontal merger between two competitors may be reduced competition in the relevant market, as well as cost savings from merging companies' $\mathrm{R} \& \mathrm{D}$ divisions, merging their sales divisions and making more efficient use of previously underutilised equipment.

The presence of $M \& A$ as a strategic tool to - among other things gain competitive advantage, penetrate new markets, create synergies. Theoretically one of the main reasons for the seemingly low success rate can be attributed to inadequate measurement of $M \& A$ performance. The first reason being executives might pursue their own personal agenda instead of the shareholders' resulting in value destruction. The second suggestion offered is that practitioners might be unaware of theoretical findings and insights provided by research. However, this is not as promising as they conclude that there is both an abundance of risk associated with M\&As in the financial press, as well as high availability of literature oriented towards practitioners.

The changing environment poses a challenge to every business, whether it is public or private, with the greatest likelihood of success being the one who will use new methods. Businesses have alternative development options, but one option must be chosen from all options.

\section{Financial gains in merger and acquisition process}

Mergers and acquisitions over the past 40 years have generated considerable interest and generated demand for strategic literature, focusing on the strategic and organisational compatibility of companies, as well as the management of mergers and acquisitions themselves. Despite the popularity and visibility of this type of transaction, one of the most interesting findings of merger and acquisition studies is that the merger has not delivered the expected result. The outcome of a merger or acquisition can be evaluated from various perspectives, such as whether the transaction has resulted in a profit for the company's shareholders. One of the calculation criteria is profitability, which can be measured and measured in the short or long term.

The measurement of the business of a merged or acquired entity is carried out by comparing the accounting data before and after the transaction (for a period of at least 3 years) and by comparing the accounting data on 
turnover and profits. Process of mergers and acquisitions has identified an important aspect to consider in order to establish a successful merger and acquisition.

Today's business strategy is based on plans and actions designed to help companies compete successfully in their industry. Its mission is to help companies achieve and exploit their competitive advantage. Strategic planning, on the other hand, must ensure the long-term development of the company and high economic growth rates. Company strategy is an important element that helps to focus the efforts to achieve goals and has a long-term character. In turn, in the process of strategy planning, the company develops possible actions and receives an answer on how to move forward.

Scientific papers analysed by the author show that financial statements data can be used to determine the activities of a company by calculating, comparing, combining and interpreting various absolute and relative indicators. One of the simplest methods of financial analysis for assessing financial stability is the horizontal method of analysis - studying changes in the absolute ratios of a company's financial statements (balance sheet, profit and loss statement, cash flow statement). Significant changes in the key financial statement items have a significant impact on the financial stability of the company. In order to carry out due diligence of the financial ratios of Latvian companies, as well as to reasonably select the variables of the model to be used, the author considers it necessary to calculate and investigate the correlation of indicators showing the closeness of correlation between two related variables. In order to determine the correlation between the company's financial performance, the author calculated the correlation coefficients, and in order to obtain a statistically significant rating interval for the correlation coefficient, both variables must correspond to the normal distribution. However, as mentioned in the previous section, this is not the case. Therefore, these ranges were not calculated and the correlation coefficients only give insight into the possible relationships and trends of the cash flow.

Regression analysis was used to show the regularities of these parameters. The obtained data were processed with Microsoft Office Excel and SPSS programs. Multivariate regressions were performed on data processing using the standard least squares (Ordinary Least Squares) method. This method minimises the sum of the squares of distance in the observed measurements. In total, 21 regressions were performed: one for each firm over several years of operation. Note that there are only 21 measurements in total, which is the minimum number of observations to ensure a normal distribution. Accordingly, due to the limited amount of data, regressions may not produce statistically significant results. In addition, it is also 
noted that the models that will be used in the regression analysis are not specifically designed to explain all fluctuations in the psychological factor, but to find correlations and to provide an overview of the performance of physical tasks.

Due to the large number of variables, a list of financial variables with potentially 22 variable ratios was used for the study. Based on the results of the study, it was concluded that several financial ratios indicate the performance of the company. The result of the detection model depends on the choice of indicators, so the correct choice of indicators provides the possibility to form a precisely working model. Various financial ratios were selected for analysis. All analysed financial ratios were divided into four groups according to their importance:

1. Liquidity;

2. Profitability;

3. Solvency; and

4. Activity.

The M\&A model is modelled on the principle that at least one factor is selected from each set of ratios that exhibits the most significant difference between related and unrelated companies in the merger process. The following procedures were performed to arrive at the variables in the equation:

1. Observation of statistical significance for various alternative functions, including each independent variable;

2. Evaluation of the correlation between the relevant variables; and

3. Accuracy of observation forecasts between different profiles.

The author believes that it is important to find out what factors affect company merger and acquisition results, how high the company's EBITDA is, and how companies with high and low levels can be classified according to a regression function.

The following indicators are used in the following study:

- $\mathrm{y}$ - EBITDA / turnover;

- $\mathrm{x} 1$ - gross profit margin ratio;

- $\quad$ x2 - profitability before interest payments;

- $\quad$ x3 - profitability ratio of taxable profit;

- x4 - commercial profitability indicator;

- x5 - return on assets ratio;

- x6 - return on equity;

- $\quad$ x7 - return on equity;

- $x 8$ - turnover of assets;

- $\quad$ x9 - turnover of fixed assets;

- x10 - current assets turnover ratio;

- x11 - total liquidity ratio; 
- x12 - current liquidity ratio;

- x13 - absolute liquidity ratio;

- x14- EBITDA / assets;

- x15 - equity / liabilities; and

- x16 - Turnover / Assets.

By performing a correlation analysis of the raw data, the dependent variable $y$ - EBITDA / turnover with the independent variables analysed is statistically significant with significance levels of 0.05 and 0.01 , resulting in a correlation coefficient matrix in which the correlation coefficients for the dependent variable with the relevant independent variables excluded are statistically significant.

The measurement of the financial results of a business combination is closely linked to the assessment of the significance of financial ratios. If the variable is EBITDA / turnover, there is a strong positive statistically significant relationship between the pre-interest profit margin, the aftertax profit margin and the commercial profitability ratio, the return on assets ratio and the EBITDA / assets valuation.

Higher EBITDA / Turnover Ratio is associated with higher average financial ratios for profit before interest, taxable profit and commercial profitability, Return on Assets, and EBITDA / Assets as evidenced by Pearson correlation coefficient values, which are statistically significant probability.

Multivariate regression analysis was used to assess the dependency of the financial results of M\&A. There is a correlation between the selected factors, which may influence the accuracy of the solution, but estimation of the correlation coefficients using inequalities: roi $>$ rij; roj $>$ rij; rock $>$ rik; rock > rjk; where o - performance indicator (EBITDA / turnover ratio estimate), i, j, k - factorial indicators (significance of profit before interest, taxable profit and commercial profitability, return on assets and significance of EBITDA / assets), Since the correlation of the factorial features with the performance trait is closer than the correlation between the factors, therefore, it is useful to include the selected factors in the regression model, there is no multicollinearity between the factorial features.

Selecting only those variables for which the EBITDA/ Turnover correlation coefficient is statistically significant with significance level 0.05 and 0.01 , the following result is obtained: In the Model Summary block of Model Summary, the author found that the coefficient of determination (R Square) equals 0.862 , indicating that $86.2 \%$ of the variance in the performance attribute is explained by the factors included in the regression equation (profit before interest profit margin (x2), taxable profit margin (x3) and commercial profitability (x4), Return on Assets (x5) and EBITDA / Assets (x14), 
Thus, the linear regression model by which to forecast EBITDA / Turnover values looks like this:

$y_{t}=0.956 x_{2, t}+0.108 x_{14, t}+0.011$

where yt - EBITDA / turnover at time t;

$\mathrm{x} 2, \mathrm{t}$ - profitability ratio before interest payments at time $\mathrm{t}$;

$\mathrm{x} 14, \mathrm{t}-$ EBITDA / assets at time $\mathrm{t}$.

The linear regression analysis included all 17 variables, of which the dependent y was EBITDA / turnover. In the linear regression analysis, the following results were obtained in the SPSS program: In the first statistical block of Model Summary we find that the resulting linear regression model $-89.5 \%$ of the variance of the result variable is explained by the factors included in the regression equation (gross profit margin (x1) profitability ratio (x2), taxable profit margin $(\mathrm{x} 3)$ and commercial profitability $(x 4)$, return on assets $(x 5)$, return on equity $(x 6)$, return on equity (x7), return on assets $(\mathrm{x} 9)$, working capital ratio $(\mathrm{x} 10)$, total liquidity ratio (x11), current liquidity ratio (x12), absolute liquidity ratio (x13), EBITDA / assets (x14), equity / liabilities (x15) and turnover / assets (x16) () $\mathrm{R}$ Square $=0.895$ ).

Analysing the parametric statistics of the optimized models, the author concludes that the best model with as many variables as possible and without the problem of multicollinearity $(\mathrm{VIF}<5)$ is as follows:

$$
y_{t}=0.932 x_{2, t}+0.001 x_{7, t}-0.012 x_{12, t}+0.074 x_{14, t}+0.007
$$

EBITDA / Turnover (y) is impacted by profitability before interest payments $(\mathrm{x} 2)$, return on equity (x7), current liquidity ratio $(\mathrm{x} 12)$ and EBITDA / assets $(\mathrm{x} 14)$. The gross margin ratio $(\mathrm{x} 1)$ does not participate in any optimized model.

As a result of the merger, the EBITDA to turnover ratio is increasing. Based on the above analysis, it is possible to formulate a number of factors affecting a company's EBITDA:

1. Net Turnover Growth: Turnover growth rate, usually expressed as a percentage of the prior period, is one of the first things that creditors, executives and professional financial analysts pay attention to when evaluating a company's business. The reason is simple - sales revenue affects virtually all other metrics. If the other variables remain constant, significant changes in net turnover will have an impact on both the company's balance sheet and profit and loss account. 
2. Profitability before interest payments: Profit before interest payments is the sum of the profitability of an activity, excluding interest payments and taxes.

3. Return on Equity: Shows the return on each euro invested by the owners in the equity of the company. This way one can compare returns with other potential types of investment.

4. Current Liquidity Ratio: Reflects the ratio of the company's current assets (excluding inventories) to current liabilities. A higher ratio indicates a higher level of liquidity (greater ability to meet a company's current liabilities). A ratio of 1.0 indicates that the carrying amount of current assets is exactly the carrying amount of the present liability.

5. EBITDA / Assets: Return on total assets is the ratio that measures EBITDA on a company's total net assets. The ratio is considered as an indicator of how effectively a company uses its assets to generate income.

\section{Conclusions}

With the business performance measurement model, investors can evaluate the companies they intend to invest in. Those companies whose MA (Merger \& Acquisition) index was much higher than the critical value have higher financial performance while those whose MA index is below critical have financial problems and need shareholder financial support. The M\&A model is a likelihood model that uses aggregated data and averages, so in some cases, the calculated MA index may not be consistent with firms in another industry. The author suggests calculating the recommended financial ratios and comparing them with industry averages, as the firm's operating efficiency and the factors affecting that efficiency are associated with certain regularities.

A high MA index demonstrates that well-organised management processes allow a company to be more efficient, productive and thus more competitive, which is essential in today's circumstances. The company manager needs to identify tasks that can increase the long-term performance of the company.

The concepts of "merger" and "takeover" differ in the integration process and over time. Horizontal integration is characteristic of mergers and acquisitions in Latvia. Risk factors in the management of the process of mergers and acquisitions are the significant difference between the planned activities and the activities actually performed, the lack of a unified methodology for the integration of the merged and the acquired company, decisions of the manager (owner), lack of cooperation between 
employees. Companies have different goals and objectives, however, the strategy of the merged and the acquired companies must be related to the mission, goals and operations of the combined company, thus becoming part of the strategic planning process of the company. Businesses planning to expand through acquisitions and acquisitions, use the author's merger and acquisition management process, define their corporate strategies for 3,5 and 10 years, base their calculations on an analysis of prior period accounting, create a team, which will help the company achieve its goals.

\section{REFERENCES}

Archibigi, D., Lundvall, B. A. (eds.). (2002). The globalizing learning economy. Oxford: Oxford University Press, pp. 307.

Ashon, J. E., Cook, F. X. Jr. \& Schmitz, P. (2003). Uncovering hidden value in a midsize manufacturing company. Harvard Business Review, 81 (6), pp. 4-12.

Barney, J. B. (2006). Gaining and Sustaining Competitive Advantage. $3^{\text {rd }}$ Revised edition. Upper Saddle River, NJ: Prentice-Hall, pp. 555.

Capron, L., Guillen, M. (2009). National corporate governance institutions and postacquisition target reorganization. Strategic Management Journal, 30, pp. 803-833.

Chen, S. F. (2008). The motives for international acquisitions: Capability procurements, strategic considerations, and the role of ownership structures. Journal of International Business Studies, pp. 454-471.

Damodaran, A. (2001). Corporate finance: theory and practice. Second edition. New York: John Wiley \& Sons, pp. 982.

Fiocco, R. (2016). The strategic value of partial vertical integration. Proceedings: Ioannina Meeting on Applied Economics \& Finance, pp. 150-151.

Gabrielsen, T. S. (2003). Conglomerate mergers: Vertical mergers in disguise? International Journal of the Economics of Business, pp. 1-16.

Haleblian, J., Devers, C. E., McNamara, G., Carpenter, M. A., Davison, R. B. (2009). Taking stock of what we know about mergers and acquisitions. A Review and Research Agenda, Journal of Management, pp. 469-502.

Heimeriks, K. H., Schijven, M., Gates, S. (2012). Manifestations of Higher-Order Routines: The Underlying Mechanisms of Deliberate Learning in the Context of Post-acquisition Integration. Academy of Management, pp. 703-726.

Hitt, M., Ireland, R. D., Hoskisson, R. E. (2001). Strategic Management edition 4. United States: South-Western College Publishing, pp. 668.

Kapoor, R., Lim, K. (2007). The impact of acquisitions on the productivity of inventors at semiconductor firms. A synthesis of knowledge-based and incentive-based perspectives. Academy of Management Journal, pp. 1133-1155.

Laikraksts Dienas Bizness. (2008). Latvijas lielākie uzṇēmumi, Top 500 par 2007. gadu, pp. 216.

Laikraksts Dienas Bizness. (2017). Latvijas lielākie uzṇēmumi, Top 500 par 2016. gadu, pp. 215. 
Lee, G. K., Lieberman. (2010). Acquisitions vs. internal development as modes of market entry. Strategic Management Journal, pp. 140-158.

Lin, Z., Peng, M. W., Yang, H., Sun, S. L. (2009). How do networks and learning drive M\&As? An institutional comparison between China and the United States. Strategic Management Journal, pp. 1113-1132.

Liu, X. (2016). Vertical integration and innovation. International Journal of Industrial Organization, pp. 88-120.

Mavḷutova, I. (2010). Uzṇēmuma tirgus vērtības paaugstināšanas iespējas restrukturizācijas rezultātā. Promocijas darbs. Rīga. Latvijas Universitāte, pp. 154.

McGahan, A. M. (2004). How industries evolve. Boston: Harvard Business School Publishing Corporation, pp. 243.

McNamara, G. M., Haleblian, J., Dykes, B. J. (2008). The performance implications of participating in an acquisition wave: Early mover advantages, bandwagon effects, and the moderating influence of industry characteristics and acquirer tactics. Academy of Management Journal, pp. 113-130.

Miller, D., Le Breton-Miller, I., Lester, R. H. (2010). Family ownership and acquisition behaviour in publicly-traded companies. Strategic Management Journal, pp. 201-223.

Recardo, R. J., Toterhi, T. (2015). Strategic Integration: How to Realize the Value of an Acquisition. Global Business \& Organizational Excellence, pp. 6-22.

Sobolev, L. (2015). Horizontal integration or conglomeration? Economic Analysis, pp. 2-11.

Volvenkins, S. (2012). Mazo un vidējo uzṇēmumu konkurētspējīgu priekšrocību radǐšana un virzīšana tirgū, izmantojot mārketinga instrumentus interneta vidē. Promocijas darbs. Rīga, pp. 192. 